\title{
Outlet Device
}

National Cancer Institute

\section{Source}

National Cancer Institute. Outlet Device. NCI Thesaurus. Code C50091.

An opening in a device that allows something to exit, commonly used to refer to an electrical power receptacle. 